\title{
Nasogastric tube check, easy or not?
}

\author{
Sara Koo
}

Department of

Gastroenterology, Darlington Memorial Hospital, Darlington, UK

\section{Correspondence to}

Dr Sara Koo,

sara.koo@gmail.com

Accepted 13 March 2016

\section{DESCRIPTION}

Our patient required nasogastric tube (NGT) feeding for poor nutritional intake. He was alert when NGT insertion occurred. This required two attempts due to coughing. On the second attempt, coughing was present throughout but settled gradually. NGT insertion may be tricky in the awake patient, especially if neurological deficits are present. Optimisation of position by sitting the patient upright and inserting the NGT horizontally and posteriorly should be undertaken. A correct insertion attempt should feel smooth, with minimal or no resistance. More importantly, the patient should not be distressed if the NGT has correctly entered the oesophagus. NGT malpositioning is suggested if coughing, respiratory distress or tachypnoea persists when the NGT has been inserted to the desired length. If this occurs, as with our patient, consider reinserting the NGT.

Chest X-ray was performed to check NGT position as no aspirate for $\mathrm{pH}$ check was obtainable (figure 1). At one glance, the NGT tip is visible below the right diaphragm, however, scrutiny may

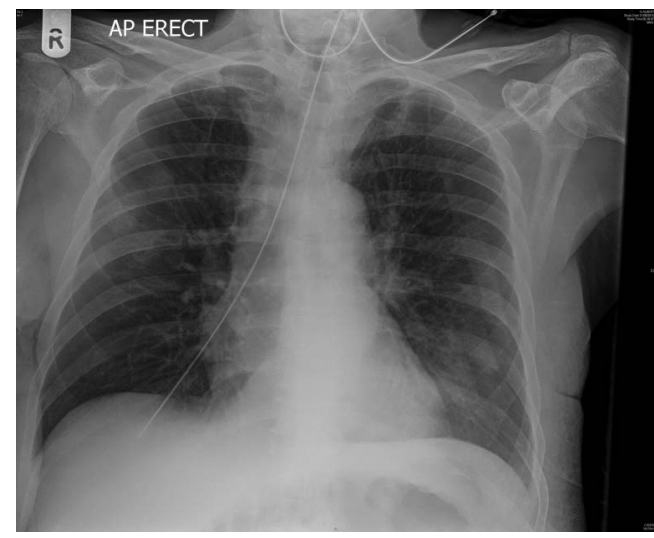

Figure 1 Chest $X$-ray showing nasogastric tube entering right main bronchus, albeit the tip is below the diaphragm. suggest otherwise. National Patient Safety Agency guidance suggests a four-step approach to confirm NGT position, the tube: (1) avoids the contours of bronchi; (2) bisects the carina; (3) crosses the diaphragm in the midline and (4) its tip is visible below the left hemidiaphragm. ${ }^{1}$ Following this approach would reveal that the NGT has entered the right main bronchus and its tip is abutting the inferior portion of the dome of the diaphragm. It has not crossed the diaphragm at the midline. Start feeding in this case would result in a disastrous outcome.

\section{Learning points}

- Clinical signs for nasogastric tube (NGT) malpositioning include coughing, respiratory distress or tachypnoea.

- Checking nasogastric (NG) aspirate $\mathrm{pH}$ is the first-line method of confirming NGT position. Chest $\mathrm{X}$-ray is performed where aspirate $\mathrm{pH}$ $>5.5$ or where no aspirate is obtainable.

- The four-step approach to chest X-ray interpretation is essential prior to NG feeding starts (NGT avoid the contours of the bronchus, bisects the carina, crosses the diaphragm in the midline and its tip is visible below the left hemidiaphragm).

Competing interests None declared.

Patient consent Obtained.

Provenance and peer review Not commissioned; externally pee reviewed.

\section{REFERENCE}

1 National Patient Safety Agency. Patient safety alert NPSA/2011/ PSA002: reducing the harm caused by misplaced nasogastric feeding tubes in adults, children and infants. 2011. http://www. nrls.npsa.nhs.uk/EasySiteWeb/getresource.axd?AssetID=129697\&

\footnotetext{
Copyright 2016 BMJ Publishing Group. All rights reserved. For permission to reuse any of this content visit http://group.bmj.com/group/rights-licensing/permissions.

BMJ Case Report Fellows may re-use this article for personal use and teaching without any further permission.

Become a Fellow of BMJ Case Reports today and you can:

- Submit as many cases as you like

- Enjoy fast sympathetic peer review and rapid publication of accepted articles

- Access all the published articles

- Re-use any of the published material for personal use and teaching without further permission

For information on Institutional Fellowships contact consortiasales@bmjgroup.com

Visit casereports.bmj.com for more articles like this and to become a Fellow
} 